Bulletin of Pharmaceutical Sciences
Assiut University
Website: http://bpsa.journals.ekb.eg/
e-mail: bullpharm@aun.edu.eg

\title{
KNOWLEDGE AND AWARENESS OF THE NOVEL CORONAVIRUS DISEASE (COVID-19) PANDEMIC AMONG EGYPTIAN POPULATION
}

\author{
Osama Mohamed Ali ${ }^{1}$, Abdurahman Salah Mohamed ${ }^{1}$, Esmael Ibrahim Mohamed ${ }^{1}$, \\ Sara Fekry Abdullah ${ }^{1}$, Sahar Badr Hassan ${ }^{2}$ and Mohamed Mahmoud Abdel-Latif ${ }^{2^{*}}$ \\ ${ }^{1}$ Clinical Pharmacy Program Student, Faculty of Pharmacy, Assiut University, Assiut, Egypt \\ ${ }^{2}$ Department of Clinical Pharmacy, Faculty of Pharmacy, Assiut University, Assiut, Egypt
}

On 11 March 2020, WHO declared the novel Coronavirus disease 2019 (COVID-19) a pandemic disease worldwide. With the rapid spread of COVID-19, Egyptians are at a high risk of being infected, as it is the most populous country in the Middle East and North Africa region. The aim of the present study was to assess the knowledge and awareness of Egyptians towards COVID-19. A nationwide cross-sectional study was performed among the general sample of the Egyptian population. One thousand one hundred fifteen individuals participated in the survey with gender distribution of 625 males and 490 females. Descriptive analysis was used to describe the study findings. Most respondents 715 (64.1\%) acknowledged that COVID-19 was a serious disease and the majority of them had a good to fair knowledge 1096 (98.3\%) about COVID-19. Nasal droplets and touching surfaces were suggested to be the common modes of transmission 1099 (98.6\%). Most respondents correctly identified the symptoms of COVID-19 of fever, dry cough and dyspnea. The main sources of information obtained from social media 979 (87.8\%), radio-television 611 (54.8\%) and Ministry of Health 568 (50.9\%). However, only $144(12.9 \%)$ of participants trusted information posted on social media, 605 (54.3\%) to some extent while $366(32.8 \%)$ didn't. Despite many participants understood the precautionary measures, but they were unsatisfactory 796 (71.4\%) with the public's behavior of obeying the national procedures. The surveyed Egyptians had a good knowledge of COVID-19 and an acceptable understanding of the precautionary measures taken by the government. However, strict national procedures are further needed to enforce such measures to combat the disease.

\section{INTRODUCTION}

The novel coronavirus disease- SARS coronavirus-2 (SARS-CoV-2), named COVID19, has emerged from Wuhan city in China in December 2019 ${ }^{1}$. On March 11, 2020, the World Health Organization declared the COVID-19 outbreak a pandemic disease, and the disease becomes one of the greatest challenges in the world ${ }^{2}$. The pandemic spread of the highly contagious COVID-19 disease around the world has put the healthcare systems of many countries under lifethreatening disease and global public health burden $^{2-4}$. The COVID-19 disease is greatly affecting the economy and humanities of the international communities with a great fear of a recession, life-threatening disease and the global health predicament ${ }^{5 \& 6}$. Preventive approaches such as vaccines that prevent COVID-19 infection and drug therapeutics that reduce the risk of infectious disease are badly needed.

Coronaviruses are enveloped, positivestranded RNA viruses with nucleocapsid. The COVID-19 is a new strain of coronavirus family of viruses that has not been previously identified in humans, that are known to cause illness ranging from the common cold to more severe diseases such as Middle East Respiratory Syndrome (MERS) and Severe Acute Respiratory Syndrome (SARS) ${ }^{7 \& 8}$. The clinical symptoms of COVID-19-infected patients may include fever, dry cough, 
abnormal chest CT, and less common symptoms such as sputum production, headache, hemoptysis, and diarrhea. Severe acute respiratory syndrome-related coronavirus (COVID-19) is an extremely infectious viral respiratory disease resulting in pneumonia ${ }^{9 \& 10}$.

Coronaviruses are thought to be the highly pathogenic and large-scale epidemic viruses in the twenty-first century, because of the emergence of the Severe Acute Respiratory Syndrome Coronavirus (SARS-CoV) in 20022003, Middle East Respiratory Syndrome Coronavirus (MERS-CoV) in 2012 and later on SARS-CoV-2 (COVID-19) in 2019 ${ }^{11}$. The COVID-19 belongs to the genus Betacoronavirus. Bats, Rhinolophus affinis are currently the known potential definitive host for SARS-CoV-2. Respiratory droplets and nasal discharge may constitute the possible route of disease transmission ${ }^{11}$. The COVID-19 affects all ages, especially elderly population with chronic diseases ${ }^{11-13}$.

In Egypt, the first confirmed case of COVID-19 was detected in Cairo international airport for a Chinese citizen and reported on 14 February $2020^{14}$. On 5 March 2020, the first Egyptian confirmed case was reported for a 44 years old man returned from Serbia and transit from France. As of August 20, 2020, there had been 97,025 confirmed cases and 5212 deaths due to the COVID-19 disease in Egypt according to the statistics reported by the Ministry of Egyptian Health and Population ${ }^{15}$.

Unfortunately, until the moment there is no vaccine, drug therapy or specific treatment has been developed for COVID-19 disease ${ }^{16 \& 17}$. Therefore, applying preventive measures to reduce the spread of the disease is of a great importance. The $\mathrm{WHO}$ and the Centers for Disease Control and Prevention (CDC) have published recommendations for the prevention and control of COVID-19 infection spread among population, including personal and hand hygiene, wearing personal protective equipment, like gloves and facemasks, to reduce transmission ${ }^{18-20}$. For purpose of mitigating the force of further spread of infection, it is crucial to increase the public knowledge, awareness and vigilance regarding the infection routes of transmission, symptoms and control measures among populations.
The spread of COVID-19 infection among people is always of public health concern, particularly when there is little knowledge and perception about the nature of the disease, the spread of infection between people, the severity of the viral infection and the treatment of the disease. The knowledge and awareness of Egyptians regarding COVID-19 disease are important in combating the infection and fighting the disease. The objectives of this study were to assess the knowledge and awareness of Egyptians about COVID-19; and the preparedness and willing of the persons to apply the preventive procedures and obey the regulatory steps in the course of COVID-19 pandemic infection.

\section{METHODS}

\section{Study design and questionnaire}

A cross-sectional online survey study was conducted on April 2020 among Egyptians. The survey was a self-structured administered questionnaire in Arabic language; the native language of Egypt, based on similar studies previously published ${ }^{21-25}$. The survey questionnaire was divided into 3 parts with a total number of 30 questions; the first part covered the demographic characteristics, the second part assessed the knowledge of the COVID-19 virus, mode of transmission, symptoms, risk group, and daily habits and the third assessed the awareness and attitude of persons about preventive measures and treatment of the disease. The age of the participants was set between 15 and more than 60 years. The ages of persons $<15$ years and Egyptians who live abroad were excluded from the study.

\section{Sample size}

The sample size was calculated using Raosoft online program ${ }^{26}$. The calculations were based on the assumption that the probability of having good knowledge on and positive awareness towards preventive measures against coronavirus disease was $50 \%$ at $99 \%$ confidence interval with a margin of error of 5\%, the calculated sample size was 662 participants. Therefore, a minimum sample size of 662 persons was required for the overall study and a total number of 1221 persons were recruited in the present study. 


\section{Validation and pilot study}

The validity and reliability of the questionnaire was assessed by an expert in the field of epidemiology and public health to ensure the questions items are relevant and can correctly measure knowledge and attitude of the Egyptians regarding COVID-19. Cronbach's alpha coefficient was calculated as a measure of internal consistency reliability ${ }^{27}$. The final questionnaire was piloted on 20 participants who were excluded later from the study sample to ensure the readability and understandability of the questionnaire.

\section{Data collection}

An online survey portal Google Form was created, and the participants were invited to complete and submit the form during the period of the study started at $5^{\text {th }}$ April 2020.

The process of calling participants to share in the survey was conducted through different social media to invite persons to participate in the study. The survey portal was closed at the end of the $30^{\text {th }}$ April 2020 when the number of the participants exceeded the sample size; and the data were collected and analyzed.

\section{Ethical approval}

The study was approved by the Faculty of Pharmacy, Assiut University. Informed consent was obtained from each participant and the submission of the survey was considered as an agreement to participate in the study. The participation in the online survey was voluntary and the confidentiality of personal information was maintained anonymous throughout the study.

\section{Statistical analysis}

Data entry and analysis was performed using Online GOOGL FORM. The Statistical Package for Social Sciences software (SPSS 22.0, Chicago, IL, USA) was used for the analysis. All responses were analyzed and descriptive statistics were used to present the results variables. Data were presented as mean and percentage (\%) for categorical variables.

\section{RESULTS AND DISCUSSION}

\section{Results \\ Demographic characteristics of the study population}

A total of 1221 survey responses were received and only 106 questionnaires were excluded from the study due to incompleteness. The study included 1115 valid questionnaires with a percentage of 580 (52\%) of the participants are between the ages of 21 to 30 years. More than half of the respondents 625 $(56.1 \%)$ were males and about $731(65.6 \%)$ of the respondents were single with regard to the marital status. Urban people constituted a higher percentage $774(69.4 \%)$ of the survey persons compared to $341(30.6 \%)$ for rural persons. The majority of participants were students $750 \quad(51.1 \%)$ with university educational level. At the university level, more than three-quarter of the participants 866 (77.7\%) were studying for bachelor's degrees. Table 1 shows the summery of the characteristics of the respondents. Persons who participated in the survey were from 26 governorates; the majority of persons were from Assiut governorate 482 (43.2\%), Cairo 100 (9\%), Sohag 73 (6.5\%), Giza 60 (5.4\%) and Qena $56(5 \%)$ and the rest of the participants were from other governorates.

\section{Knowledge of COVID-19}

The majority of the respondents had a good to fair knowledge 1096 (98.3\%) about COVID-19 (Fig. 1A) and most respondent $1085(97.3 \%)$ indicated that COVID-19 was a viral infection. With regard to the seriousness of the disease, most of participants 715 (64.1\%) believed that COVID-19 is serious, $388(34.8 \%)$ believed to some extent serious and $12(1.1 \%)$ not serious (Fig. 1B). On the other hand; about half of the participants 559 $(50.1 \%)$ believed that COVID-19 was transmitted to Egypt from people who were coming from countries other than china, while $417(37.4 \%)$ china and 139 (12.5\%) didn't know (Fig. 1C). 
Table 1: Socio-demographic characteristics of the participants.

\begin{tabular}{|c|c|}
\hline Item & $\begin{array}{c}\text { Number }(\%) \\
\mathrm{No}=1115\end{array}$ \\
\hline $\begin{array}{l}\text { 1- Gender } \\
\text { a. Male } \\
\text { b. Female } \\
\end{array}$ & $\begin{array}{l}625(56.1 \%) \\
490(43.9 \%)\end{array}$ \\
\hline $\begin{array}{l}\text { 2- Age group } \\
\begin{aligned} \text { a. } & 15-20 \text { years } \\
\text { b. } & 21-30 \text { years } \\
\text { c. } & 31-40 \text { years } \\
\text { d. } & 41-50 \text { years } \\
\text { e. } & 51-60 \text { years } \\
\text { f. } & <60 \text { years }\end{aligned}\end{array}$ & $\begin{array}{c}231(20.7 \%) \\
580(52 \%) \\
191(17.1 \%) \\
82(7.4 \%) \\
20(1.8 \%) \\
11(1 \%) \\
\end{array}$ \\
\hline $\begin{array}{l}\text { 3- Marital status } \\
\text { a. Single } \\
\text { b. Married } \\
\text { c. Divorced } \\
\text { d. Widow } \\
\end{array}$ & $\begin{array}{c}731(65.6 \%) \\
368(33 \%) \\
8(0.7 \%) \\
8(0.7 \%) \\
\end{array}$ \\
\hline $\begin{array}{l}\text { 4- Education } \\
\text { a. Ph.D } \\
\text { b. Master } \\
\text { c. Diplom } \\
\text { d. University } \\
\text { e. High school } \\
\text { f. Primary and preparatory } \\
\text { school } \\
\text { g. Illiterate } \\
\end{array}$ & $\begin{array}{c}19(1.7 \%) \\
40(3.6 \%) \\
98(8.8 \%) \\
866(77.7 \%) \\
63(5.7 \%) \\
23(2.1 \%) \\
5(0.5 \%)\end{array}$ \\
\hline $\begin{array}{l}\text { 5- Occupation } \\
\text { a. Student } \\
\text { b. Education } \\
\text { c. Health } \\
\text { d. Engineering } \\
\text { e. Agriculture } \\
\text { f. Industry } \\
\text { g. Military } \\
\text { h. Administration } \\
\text { i. Law } \\
\text { j. Business } \\
\text { k. Media } \\
\text { l. Artist } \\
\text { m. Retired } \\
\text { n. Unemployed } \\
\text { o. Others } \\
\end{array}$ & $\begin{array}{c}570(51.1 \%) \\
97(8.7 \%) \\
117(10.5 \%) \\
31(2.8 \%) \\
45(22.5 \%) \\
12(1.1 \%) \\
5(0.4 \%) \\
34(3 \%) \\
14(1.3 \%) \\
57(5.1 \%) \\
2(0.2 \%) \\
2(0.2 \%) \\
7(0.6 \%) \\
105(9.4 \%) \\
59(5.3 \%)\end{array}$ \\
\hline $\begin{array}{l}\text { 6- Living area } \\
\text { a. Urban } \\
\text { b. Rural }\end{array}$ & $\begin{array}{l}774(69.4 \%) \\
341(30.6 \%)\end{array}$ \\
\hline
\end{tabular}
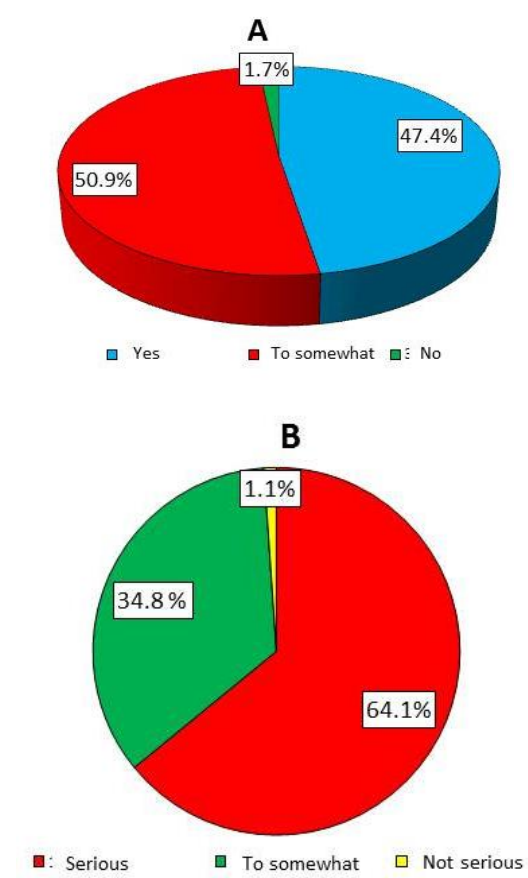

c

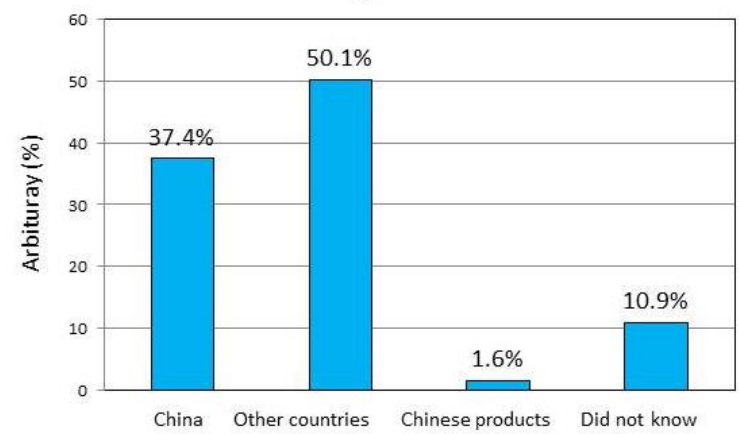

Fig. 1: (A) Knowledge of COVID-19, (B) Seriousness of COVID-19, (C) Ways of transmission of COVID-19 to Egypt.

With regard to the knowledge of the participants of the modes of transmission; nasal droplets and touching surfaces by affected persons were the common method of transmission reported by the respondents 1099 (98.6\%), spread through the air 230 (20.6\%), contact with animal $203(18.2 \%)$, urine and stools $87(7.8 \%)$ and insects and mosquitoes 53 $(4.8 \%)$, as shown in table 2 . In relation to the symptoms of COVID-19; the responses of the respondents reported that the most common symptoms were fever 1049 (94.1\%), dry cough 1009 (90.5\%) and dyspnea 1007 (90.3\%), followed by sneezing and runny nose 372 (33.4\%), diarrhea 277 (24.8\%), headache 273 $(24.5 \%)$ and vomiting $124(11.1 \%)$, as shown in table 2 . 
Table 2: Knowledge and attitude of the participants towards COVID-19 infection.

\begin{tabular}{|c|c|}
\hline Question & Number $(\%)$ \\
\hline \multicolumn{2}{|l|}{ Modes of transmission of COVID-19 } \\
\hline a) Nasal droplets and surfaces touched by of affected persons & $1099(98.6 \%)$ \\
\hline b) Spread through the air & $230(20.6 \%)$ \\
\hline c) Contact with animals & $20318.2 \%)$ \\
\hline d) Stool and urine & $87(7.8 \%)$ \\
\hline e) Mosquito and insects & $53(4.8 \%)$ \\
\hline \multicolumn{2}{|l|}{ Symptoms of COVID-19 disease } \\
\hline a) Fever & $1049(94.1 \%)$ \\
\hline b) Dry cough & $1009(90.5 \%)$ \\
\hline c) Difficulty in breathing & $1007(90.3 \%)$ \\
\hline d) Sneezing & $372(33.4 \%)$ \\
\hline e) Diarrhea & $277(24.8 \%)$ \\
\hline f) Headache & $273(24.5 \%)$ \\
\hline g) Vomiting & $124(11.1 \%)$ \\
\hline \multicolumn{2}{|l|}{ Ways of spread of COVID-19 infection } \\
\hline a) Overcrowding and public transportation & $1058(94.9 \%)$ \\
\hline b) Lack of daily personal hygiene & $909(81.5 \%)$ \\
\hline c) Going to shopping & $667(59.8 \%)$ \\
\hline d) Going to cafeterias & $638(57.2 \%)$ \\
\hline e) Going to public restaurants & $516(46.3 \%)$ \\
\hline f) Going to clubs & $455(40.8 \%)$ \\
\hline \multicolumn{2}{|l|}{ People with high risk of COVID-19 infection } \\
\hline a) Older people & $1047(93.9 \%)$ \\
\hline b) Patients with chronic diseases & $956(85.7 \%)$ \\
\hline c) Pregnant women & $461(41.3 \%)$ \\
\hline d) Children & $231(20.7 \%)$ \\
\hline e) Adults & $96(8.6 \%)$ \\
\hline f) Do not know & $27(2.4 \%)$ \\
\hline \multicolumn{2}{|l|}{ Sources of information about COVID-19 } \\
\hline a) Social media & $979(87.8 \%)$ \\
\hline b) Radio and television & $611(54.8 \%)$ \\
\hline c) Ministry of Health and Population & $568(50.9 \%)$ \\
\hline d) Newspapers & $265(23.8 \%)$ \\
\hline e) Friends & $242(21.7 \%)$ \\
\hline f) Street chatters & $202(18.1 \%)$ \\
\hline g) Relatives & $189(17 \%)$ \\
\hline h) workplace & $155(13.9 \%)$ \\
\hline \multicolumn{2}{|l|}{ Actions taken when they infected with COVID-19 } \\
\hline a) Isolate themselves in a separate room away from others & $894(80.2 \%)$ \\
\hline b) Call helpline 105 or ambulance & $645(57.8 \%)$ \\
\hline c) Go to hospital & $440(39.5 \%)$ \\
\hline d) Take drug analgesics & $204(18.3 \%)$ \\
\hline e) Consult relatives & $34(3 \%)$ \\
\hline f) Follow daily routine life & $24(2.2 \%)$ \\
\hline g) Do not know & $26(2.3 \%)$ \\
\hline
\end{tabular}




\section{Awareness of the participants of the ways of spread of COVID-19 and risk factors of infection}

The majority of the respondents 1058 (94.9\%) believed that overcrowding and public transportation was the main cause of COVID19 spread. About 909 (81.5\%) of participants reported that COVID-19 spread was due to the lack of daily personal hygiene. Furthermore the participants ranked the other causes of COVID19 spread as follow: $667(59.8 \%)$ was due to going shopping, 638 (57.2\%) was due to going to cafeterias, $516(46.3 \%)$ was due to going to public restaurants and $455(40.8 \%)$ was due to going to clubs. The respondents also reported that older people at higher risk of being infected 1047 (93.9\%), people with chronic diseases 956 (85.7\%), pregnant women 461 (41.3\%), children 231 (20.7\%), adults 96 $(8.6 \%)$ and $27(2.4 \%)$ didn't know. Table 2 shows the reported different ways of spread of COVID-19 and risk factors of infection.

\section{The respondents' responses to precautionary measures of COVID-19}

With regard to the adherence of persons to the precautionary steps taken by the government; the respondents reported that about $796(71.4 \%)$ of them were not satisfied with peoples' actions and behaviors, 204 (18.3\%) satisfied and only 115 (10.3\%) didn't know (Fig. 2A). With regard to the responses of the participants to precautionary measures, the majority of the respondents were strongly agreed or agreed on obeying the procedures of social distancing and public and personal hygiene health as shown in table 3 . More than half of the participants $604(54.2 \%)$ believed that the patient is mandatory to wear the facemask, $575(51.6 \%)$ medical staff only, 549 (49.2\%) all people, 445 (39.9\%) patients with chronic diseases and only $52(4.7 \%)$ of them said that the use of the facemask didn't have any role in protecting against COVID-19 (Fig. 2B). When the participants asked about the means of COVID-19 detection methods, three quarter of participant $853(76.5 \%)$ stated that COVID-19 detection were insufficient, 67 (8.7\%) sufficient and 165 (14.8\%) didn't know.
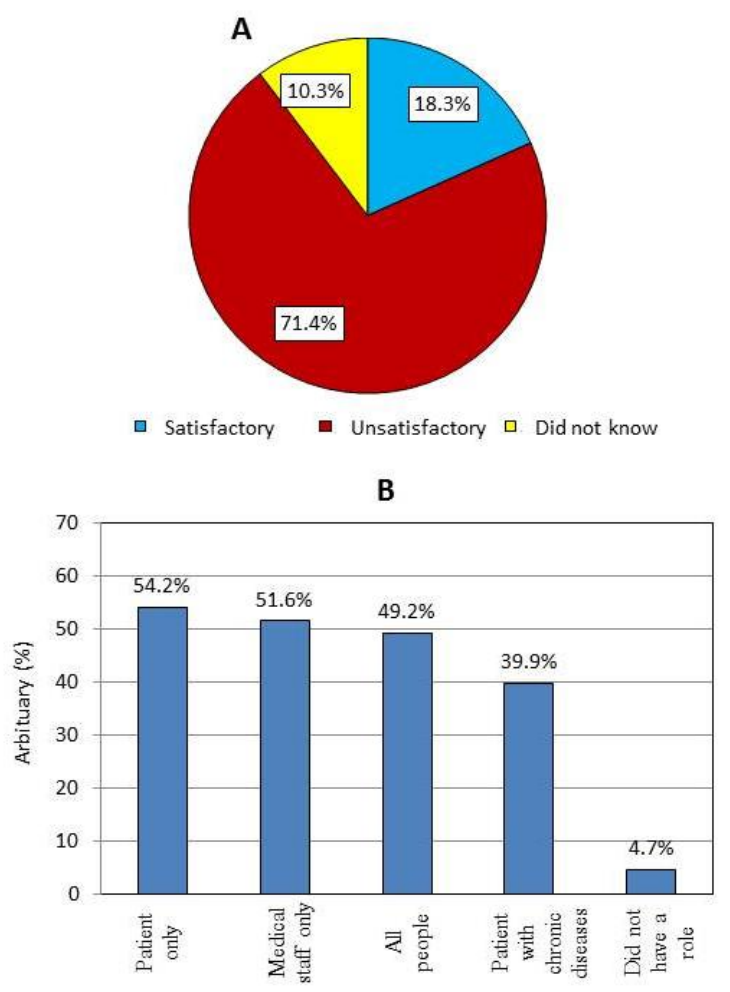

Fig. 2: (A) Respondents' response to: (A) the adherence to the precautionary steps taken by the government, (B) The use of facemask.

\section{Knowledge of sources of information about COVID-19}

The information around COVID-19 is changing rapidly every day and we are seeing a lot of misinformation being posted on different media channels, when we asked the participants about their sources for information on COVID-19, more than three quarter of respondents $979(87.8 \%)$ stated that COVID-19 from social media, $611 \quad(54.8 \%)$ radiotelevision, 568 (50.9\%) Ministry of Health and Population, 265 (23.8\%) newspapers, 242 $(21.7 \%)$ friends, $202(18.1 \%)$ street chatters, $189(17 \%)$ relatives and only 155 (13.9\%) work place. On questioning the respondents about the reliability of COVID-19 information posted; only $144(12.9 \%)$ believed that information about COVID-19 was correct, 605 (54.3\%) to some extent correct, 366 (32.8\%) did not believe such information as shown in table 2 . 
Table 3: The respondents' responses to precautionary measures to prevent COVID-19.

\begin{tabular}{|c|c|c|c|c|c|}
\hline \multirow[b]{2}{*}{ Item } & \multicolumn{5}{|c|}{ Respondents' responses $(\mathrm{N}=1115)$} \\
\hline & $\begin{array}{l}\text { Strongly } \\
\text { agree }\end{array}$ & Agree & Neutral & Disagree & $\begin{array}{l}\text { Strongly } \\
\text { disagree }\end{array}$ \\
\hline $\begin{array}{l}\text { Avoid contact with the infected } \\
\text { persons }\end{array}$ & $\begin{array}{c}1101 \\
(98.7 \%) \\
\end{array}$ & $\begin{array}{c}104 \\
(9.3 \%)\end{array}$ & - & - & - \\
\hline Wash hands with soap and water & $\begin{array}{c}1029 \\
(92.3 \%)\end{array}$ & $\begin{array}{c}68 \\
(7.7 \%)\end{array}$ & - & - & - \\
\hline $\begin{array}{l}\text { Use of own personal toiletry } \\
\text { tools }\end{array}$ & $\begin{array}{c}858 \\
(77 \%) \\
\end{array}$ & $\begin{array}{c}227 \\
(20.4 \%) \\
\end{array}$ & $\begin{array}{c}30 \\
(2.7 \%) \\
\end{array}$ & - & - \\
\hline $\begin{array}{l}\text { Avoid touching infected surfaces } \\
\text { and utensils }\end{array}$ & $\begin{array}{c}907 \\
(81.3 \%)\end{array}$ & $\begin{array}{c}195 \\
(17.5 \%)\end{array}$ & $\begin{array}{c}13 \\
(1.2 \%)\end{array}$ & & \\
\hline $\begin{array}{l}\text { Avoid people masses and } \\
\text { overcrowded places }\end{array}$ & $\begin{array}{c}950 \\
(85.2 \%) \\
\end{array}$ & $\begin{array}{c}147 \\
(13.1 \%) \\
\end{array}$ & $\begin{array}{c}18 \\
(1.6 \%) \\
\end{array}$ & - & - \\
\hline $\begin{array}{l}\text { Cover nose and mouth with the } \\
\text { elbow when coughing or } \\
\text { sneezing }\end{array}$ & $\begin{array}{c}898 \\
(80.5 \%)\end{array}$ & $\begin{array}{c}182 \\
(16.3 \%)\end{array}$ & $\begin{array}{c}21 \\
(1.9 \%)\end{array}$ & $\begin{array}{c}14 \\
(1.3 \%)\end{array}$ & - \\
\hline Use of facemask and gloves & $\begin{array}{c}492 \\
(44.1 \%)\end{array}$ & $\begin{array}{c}416 \\
(37.3 \%)\end{array}$ & $\begin{array}{c}156 \\
(14 \%)\end{array}$ & $\begin{array}{c}40 \\
(3.6 \%)\end{array}$ & $11(1 \%)$ \\
\hline $\begin{array}{l}\text { Avoid touching the nose, mouth } \\
\text { and eyes }\end{array}$ & $\begin{array}{c}881 \\
(79 \%)\end{array}$ & $\begin{array}{c}203 \\
(18.2 \%) \\
\end{array}$ & $\begin{array}{c}23 \\
(2.1 \%)\end{array}$ & - & - \\
\hline Avoid handshaking & $\begin{array}{c}813 \\
(72.9 \%) \\
\end{array}$ & $\begin{array}{c}252 \\
(22.6 \%) \\
\end{array}$ & $\begin{array}{c}40 \\
(3.6 \%) \\
\end{array}$ & $\begin{array}{c}10 \\
(0.9 \%) \\
\end{array}$ & \\
\hline $\begin{array}{l}\text { Avoid eating in restaurants and } \\
\text { cafeterias }\end{array}$ & $\begin{array}{c}810 \\
(72.7 \%)\end{array}$ & $\begin{array}{c}240 \\
(21.5 \%)\end{array}$ & $\begin{array}{c}48 \\
(4.3 \%)\end{array}$ & $\begin{array}{c}17 \\
(1.5 \%)\end{array}$ & \\
\hline Use antiseptics/disinfectants & $\begin{array}{c}799 \\
(71.7 \%) \\
\end{array}$ & $\begin{array}{c}287 \\
(25.7 \%) \\
\end{array}$ & $\begin{array}{c}29 \\
(2.6 \%) \\
\end{array}$ & & \\
\hline Cook foods well & $\begin{array}{c}733 \\
(65.7 \%)\end{array}$ & $\begin{array}{c}240 \\
(21.5 \%)\end{array}$ & $\begin{array}{c}48 \\
(4.3 \%)\end{array}$ & $\begin{array}{c}17 \\
(1.5 \%)\end{array}$ & \\
\hline $\begin{array}{l}\text { Avoid transportation by taxi and } \\
\text { public transportation }\end{array}$ & $717(64.3 \%)$ & $\begin{array}{c}231 \\
(28 \%)\end{array}$ & $\begin{array}{c}73 \\
(6.5 \%) \\
\end{array}$ & $\begin{array}{c}13 \\
(1.2 \%) \\
\end{array}$ & \\
\hline $\begin{array}{l}\text { Set a social distancing of one } \\
\text { meter away from others and } \\
\text { salute the guests by handwaving, } \\
\text { gesture or bending }\end{array}$ & $\begin{array}{c}656 \\
(58.8 \%)\end{array}$ & $\begin{array}{c}333 \\
(29.9 \%)\end{array}$ & $\begin{array}{c}28 \\
(2.5 \%)\end{array}$ & $\begin{array}{c}10 \\
(0.9 \%)\end{array}$ & \\
\hline
\end{tabular}

\section{Opinions of respondents' actions if they got infected with COVID-19}

Upon questioning about the their actions when they were suffering from these symptoms; most of the participants stated they would isolate themselves in a separate room away from others $894(80.2 \%)$, call helpline 105 or ambulance $645(57.8 \%)$, go to hospital $440(39.5 \%)$, take drug analgesics $204(18.3 \%)$, consult relatives $34(3 \%)$, continue normally with their daily routine life $24(2.2 \%)$ and 26 (2.3\%) didn't know as shown in table 2.

\section{Views of the participants about treatment of COVID-19}

Upon questioning the participants' knowledge about COVID-19 vaccination and treatment, most of the respondents answered that there is no treatment for COVID-19 713 $(63.9 \%), 83(7.5 \%)$ there is an effective treatment for the disease, $78(7 \%)$ there is a treatment but ineffective, and 241 (21.6\%) didn't know (Fig. 3A). With regard to the participants' response of the use of antibiotics in treating COVID-19, 746 (66.9\%) reported that it is ineffective, $339(30.4 \%)$ effective to some extent, and $30(2.7 \%)$ effective as shown 
in figure 3B. Furthermore, regarding the use of dietary and herbal medicines in combating the disease, most of the respondents recommended eating fruits and vegetables 721 (64.7\%), drinking water and fresh juices 699 (62.7\%), taking vitamins and minerals 483 (43.4\%), taking herb medicines 441 (39.6\%), and taking painkillers and medications $95(8.5 \%)$, as shown in table 4.
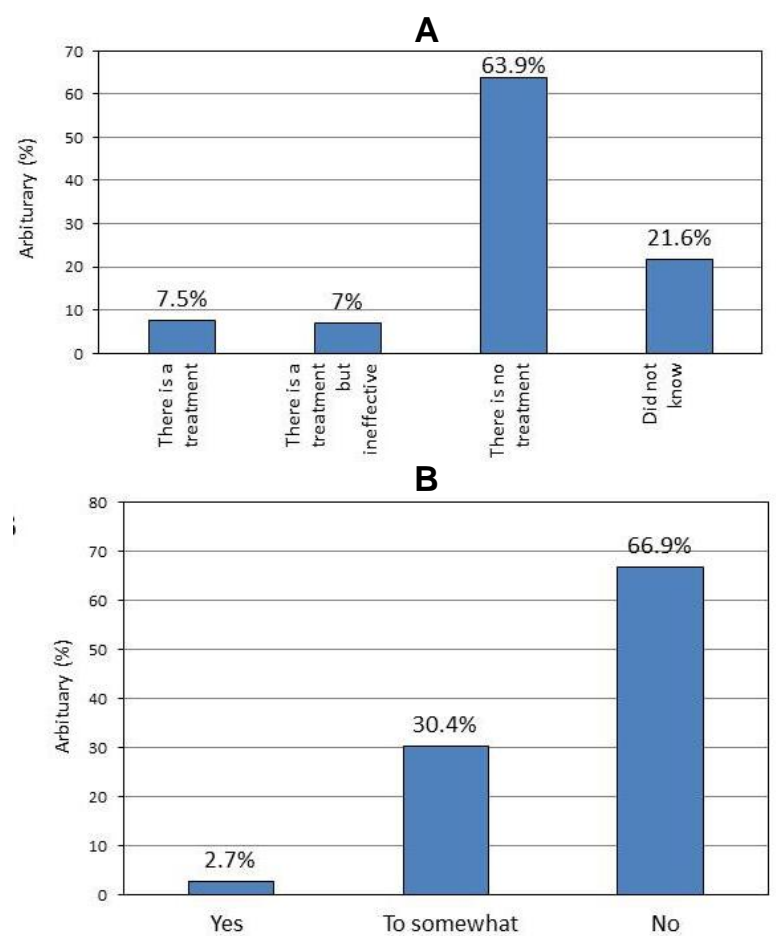

Fig. 3: (A) Views of the respondents towards treatment of COVID-19 (A) and the use of antibiotics in treating COVID-19 (B).
Views of the participants about their life rituals after COVID-19 termination

Persons had different feeling views about their life rituals after the end of COVID-19 outbreak. About half of the participants 505 $(45.3 \%)$ proclaimed they would deal with people with extreme caution and avoid handshaking, $436(39.1 \%)$ follow routine daily life, $61(5.5 \%)$ afraid of going out or going to work and $113(10.1 \%)$ didn't know what to do after the end of the pandemic crisis (Fig. 4).

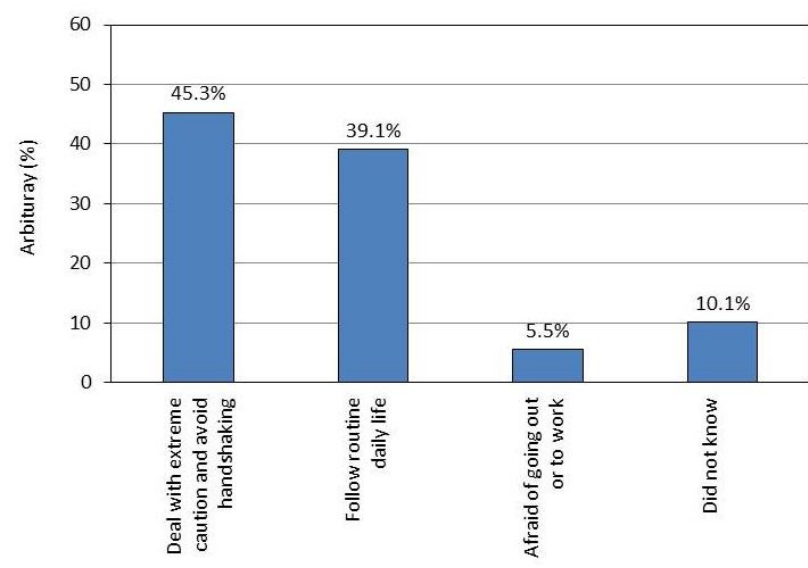

Fig. 4: Respondents' feeling after the end of COVID-19 disease.

Table 4: The respondents' responses to lifestyle and home remedies to prevent COVID-19.

\begin{tabular}{|l|c|c|c|c|}
\hline \multirow{2}{*}{\multicolumn{1}{|c|}{ Item }} & \multicolumn{4}{|c|}{ Respondents' responses (N=1115) } \\
\cline { 2 - 5 } & Always (\%) & Often (\%) & Seldom (\%) & Never (\%) \\
\hline $\begin{array}{l}\text { Drink water and fresh } \\
\text { juice }\end{array}$ & $699(62.7 \%)$ & $343(30.8 \%)$ & $38(3.4 \%)$ & $35(3.1 \%)$ \\
\hline Eat fruits and vegetables & $721(64.7 \%)$ & $342(30.7 \%)$ & $34(3 \%)$ & $18(1.6 \%)$ \\
\hline $\begin{array}{l}\text { Take vitamins and } \\
\text { minerals }\end{array}$ & $483(43.4 \%)$ & $362(32.5 \%)$ & $162(14.6 \%)$ & $108(9.7 \%)$ \\
\hline Taking herbal mediicnes & $441(39.6 \%)$ & $397(35.6 \%)$ & $182(16.3 \%)$ & $95(8.5 \%)$ \\
\hline $\begin{array}{l}\text { Taking drugs and } \\
\text { analgesics }\end{array}$ & $95(8.5 \%)$ & $228(20.5 \%)$ & $328(29.5 \%)$ & $464(41.6 \%)$ \\
\hline
\end{tabular}




\section{Discussion}

In a survey of 1115 diverse Egyptian people of COVID-19 knowledge administered during April 2020, we found that most respondents acknowledged the threat of COVID-19 outbreak to be serious, and they were very worried of contracting the contagious virus and affecting their daily routine life and general health. Egypt is the most populous country in the Middle East and North Africa (MENA) region with a population of more than 100 million people ${ }^{28}$. The potential for rapid spread associated with COVID-19 and the risk of severe disease in such high inhabitants can lead to very high population morbidity and mortality. Therefore, the comprehension of the personal knowledge and awareness of the COVID-19 disease is of a great concern in order to limit the spread of the infection and recommend best practices and management approaches of the disease. Our study also demonstrated a high knowledge among Egyptians and a positive attitude towards the precautionary measures and preventive procedures. These findings may add informative insights to the government and health authorities to deal with this pandemic crisis and enforce the precautionary and preventive measures taken.

In relation to travelling during the spread of COVID-19 pandemic through the period from $1^{\text {st }}$ January until $30^{\text {th }}$ April 2020; more than half of participants didn't travel abroad and $30 \%$ traveled inside the country. Half of Egyptians' participants thought that COVID-19 was transmitted to Egypt with people who were coming from China and other countries as Egypt is considered a tourist country. As for COVID-19 transmission, the majority have chosen the disease is being transmitted via nasal droplets and touching surfaces. On the other hand, they emphasized that COVID-19 detection measures at airports, sea and land ports were insufficient, and stronger testing procedures should be followed. With regard to the symptoms; most of the respondents were knowledgeable of the most common bothersome symptoms of COVID-19 including fever, dry cough and dyspnea. A higher percentage of the respondents stated they stated that when suffering from these symptoms, they would isolate themselves as a first action or call the hotline (105)/ambulance. The majority of the respondents had a positive attitude to self-adherence to the precautionary measures of avoiding contact with infected people and overcrowding, using personal hygiene and facemask, covering the nose and mouth when coughing or sneezing and avoiding touching the nose, mouth and eyes. Furthermore, they had also trying to avoid the routine habits of the daily life such as avoidance of shaking hands, eating in restaurants and cafeterias, public transportation; using hand antiseptics, cooking foods well and keeping social distancing.

Approximately half of the respondents $529(47.4 \%)$ stated that they have sufficient knowledge of COVID-19 pandemic. However, we noted that the participants' knowledge of COVID-19 is greatly dependent on social media as a source of health information. In our study, we found more than three-quarter of the respondents used social media $979(87.8 \%)$ as a first priority of COVID-19 information followed by radio-television $611(54.8 \%)$ and Ministry of Health and Population 568 (50.9\%) as the main sources of information about Coronavirus. The fact that information posted on social media is questionable, because it raises the issue of the type and content of information. These findings are consistent with several previous studies from different countries demonstrating the significance of social media in health education and promotion $^{25 \& 29}$.

Despite there was a daily update from the government about COVID-19 outbreak and precautionary procedures taken by the state, However, the spread of misinformation about COVID-19 on social media has led to confusion and fear making it hard and confusing to find trustworthy information sources and reliable advice. While social media may help support educational initiatives and preventive measures to enable people to get the right kind of information on COVID-19, but many users try to make matters worse in their attempts to capitalize on the outbreak crisis $^{25 \& 29}$. Regardless of precautionary measures and warnings taken by the government, but these measures didn't have much impact on people's reaction, as a high proportion of the respondents were not satisfying with people's behavior to follow instructions which suggests that these 
precautionary measures didn't have any influential effect on the people's attitude.

Our study demonstrated that most of the respondents thought that elderly people 1047 (93.9\%) and patients with chronic illness 956 (85.7\%) are at a high risk of COVID-19. Consistent with our findings, similar recent reports about COVID-19 showed that older adults and those with underlying health conditions are at greatest risk for severe infection and death due to COVID-19 $9^{30-32}$. Unfortunately, there are several reports around the world indicated that COVID-19 pandemic affects those recovering from it again to dissipate hopes of immunity and clearly these reports highlight the importance of pursuing the preventive measures and obeying national instructions to limit the spread of the disease. This has led to a scare among people and having confusing feeling after COVID-19 recovery and interaction with people in a usual manner. After recovering, COVID-19 patients strive to know when to stop isolating and back to a daily routine and a normal life. Despite most respondents declared that there was no treatment for COVID-19, about 339 (30.4\%) of the respondents thought that the use of antibiotics might be effective to some extent in treatment of COVID-19. Furthermore, they had a great willing to follow preventive regimens to combat the infection by eating fruits and vegetables, drinking water and fresh juices, taking vitamins, minerals and medicinal herbs, and taking painkillers and medications may prevent the infection.

\section{Study limitations}

The first limitation is our study was the use of a web-based survey which might be an obstacle to illiterate persons to participate in the study. Secondly, persons who do not have an access to the internet or do not use the social media could not participate in the study. Thirdly, we could not perform the study in a questionnaire paper format due to the precautionary and preventive measures taken regarding COVID-19 to limit the spread of the disease. Finally, despite the study was online survey but most of the participants were from Upper Egypt governorates and further studies to highlight the knowledge and awareness of the rest of the country is of great importance.
This study revealed that Egyptians had a good knowledge about COVID-19, and a positive attitude towards precautionary and national measures, which is important to prevent the spread of the disease. Despite concern regarding the growing outbreak of COVID-19 disease and the necessitating social distancing and other measures to protect public health, the persons were not changing daily routine or work plans. Furthermore, regardless of the key actions taken by the government to prevent the spread of the disease, more efforts are needed to educate the public regarding the contagiousness and severity of COVID-19. Finally, more attention should be given to social media resources concerning the content and reliability of information, as they considered as effective methods of disseminating health information and promoting public health education. Further large-scale studies from other regions in Egypt are needed to advance our knowledge of COVID-19 at the national level.

\section{Acknowledgments}

We thank all the study participants for their voluntary participation in the study and for providing essential information.

\section{REFERENCES}

1- Z. Wu and J. M. McGoogan, "Characteristics of and important lessons from the coronavirus disease 2019 (COVID-19) outbreak in China: Summary of a report of 72314 cases from the Chinese Center for Disease Control and Prevention", Journal of American Medical Association, doi.org/10.1001/ jama.2020.2648 (2020).

2- WHO. Coronavirus Disease (COVID-19) Pandemic, Available at https://www.who. int/emergencies/diseases/novel-coronavirus-2019 (2020).

3- WHO. COVID-2019 Situation Report-51, Available at https://www.who.int/docs/ default-source/coronaviruse/situationreports/20200311-sitrep-51-covid-19.pdf? sfvrsn=1ba62e57_10 (2020).

4- Worldometer. COVID-19 Coronavirus Pandemic, Available at https://www. worldometers.info/coronavirus/ (2020). 
5- European Centre for Disease Prevention and Control, ECDC, "Coronavirus disease 2019 (COVID-19) pandemic: Increased transmission in the EU/EEA and the UK seventh update, 25 March (2020). Stockholm", Available at https://www. ecdc.europa.eu/sites/default/files/documen ts/RRA-seventh-update-Outbreak-ofcoronavirus-disease-COVID-19.pdf (2020).

6- T. Laing, "The economic impact of the Coronavirus 2019 (Covid-2019): Implications for the mining industry", The Extractive Industries and Society, doi:10.1016/j.exis.2020.04.003 (2020).

7- S. Segal and D. Gerstel, "The Global Economic Impacts of COVID-19", Centre for Strategic and International Studies. 1616 Rhode Island Avenue, NW

Washington. Available at https://www. csis.org/analysis/global-economicimpacts-covid-19 (2020).

8- Y. A. Helmy, M. Fawzy, A. Elaswad, A. Sobieh, S. P. Kenney and A. A. Shehata, "The COVID-19 Pandemic: A comprehensive review of taxonomy, genetics, epidemiology, diagnosis, treatment, and control", Journal of Clinical Medicine, 9 (4), pii:E1225 (2020).

9- Y. C. Li, W. Z. Bai and T. Hashikawa, "The neuroinvasive potential of SARSCoV2 may play a role in the respiratory failure of COVID-19 patients", Journal of Medical Virology, doi.org/10.1002/jmv. 25728 (2020).

10- C. Huang, Y. Wang, X. Li, L. Ren, J. Zhao, Y. Hu, L. Zhang, G. Fan, J. Xu, X. Gu, Z. Cheng, T. Yu, J. Xia, Y. Wei, W. Wu, X. Xie, W. Yin, H. Li, M. Liu, Y. Xiao, H. Gao, L. Guo, J. Xie, G. Wang, R. Jiang, Z. Gao, Q. Jin, J. Wang and B. Cao, "Clinical features of patients infected with 2019 novel coronavirus in Wuhan China", The Lancet, 395 (10223), 497-506 (2020).

11- Y. R. Guo, Q. D. Cao, Z. S. Hong, Y. Y. Tan, S. D. Chen, H. J. Jin, K. S. Tan, D. Y. Wang and Y. Yan, "The origin, transmission and clinical therapies on coronavirus disease 2019 (COVID-19) outbreak-an update on the status", Military Medical Research, 7 (1), 10 (2020).
12- L. Kai, C. Ying, L. Ruzheng and $\mathrm{H}$. Kunyuan, "Clinical features of COVID-19 in elderly patients: A comparison with young and middle-aged patients", Journal of Infection, doi: 10.1016/j.jinf.2020. 03.005 (2020).

13- J. Xu, S. Zhao, T. Teng, A. E. Abdalla, W. Zhu, L. Xie, Y. Wang and X. Guo, "Systematic comparison of two animal-tohuman transmitted human coronaviruses: SARS-CoV-2 and SARS-CoV", Viruses, 12 (2), pii, E244 (2020).

14- X. Peng, X. Xu, Y. Li, L. Cheng, X. Zhou and B. Ren, "Transmission routes of 2019$\mathrm{nCoV}$ and controls in dental practice",

International Journal of Oral Sciences, 12 (1), 9 (2020).

15- WHO. COVID-2019 situation report-26, Available at https://www.who.int/docs/ default-source/coronaviruse/situationreports/20200215-sitrep-26-covid-19.pdf? sfvrsn=a4cc6787_2 (2020).

16- Ministry of Egyptian Health and Population, MOPH, Available at https://www.mohp.gov.eg/ (2020).

17- G. Pascarella, A. Strumia, C. Piliego, F. Bruno, R. Del Buono, F. Costa, S. Scarlata and F. E. Agrò, "COVID-19 diagnosis and management: A comprehensive review", Journal of Internal Medicine, doi:10.1111/joim.13091 (2020).

18- M. Cascella, M. Rajnik, A. Cuomo, S. C. Dulebohn and R. Di Napoli, "Features, Evaluation and Treatment Coronavirus (COVID-19), in StatPearls", Treasure Island, FL: StatPearls Publishing LLC (2020).

19- WHO. Rational use of personal protective equipment for coronavirus disease (COVID-19) and considerations during severe shortages, Available at https://www.who.int/emergencies/diseases /novel-coronavirus-2019 (2020).

20- The Centers for Disease Control and Prevention, CDC, Available at https://www.cdc.gov/coronavirus/2019ncov/prevent-getting-sick/prevention.html (2020).

21- WHO. Frequently asked questions on Meddle East respiratory syndrome coronavirus (MERS-CoV) Geneva, 
Available at https://www.who.int/csr/ disease/coronavirus_infections/faq/en/ (2019).

22- L. S. Hung, The SARS epidemic in Hong Kong: What lessons have we learned?", Journal of the Royal Society of Medicine, 96 (8), 374-378 (2003).

23- A. M. Asaad, R. H. El-Sokkary, A. I. Aedh, M. A. A. Alzamanan and F. O. Khalil, "Exploring knowledge and attitude toward middle east respiratory syndromecoronavirus (MERS-CoV) among university health colleges' students, Saudi Arabia: A Cross-sectional study", American Journal of Infectious Diseases, 15 (1), 37-43 (2019).

24- F. Alshammari, "Knowledge and perception of health practitioners towards MERS-CoV in Hail Region, Kingdom of Saudi Arabia", American Journal of Nursing Research, 6 (1), 12-17 (2018).

25- A. Al-Hazmi, I. Gosadi, A. Somily, S. Alsubaie and A. Bin Saeed, "Knowledge, attitude and practice of secondary schools and university students toward Middle East Respiratory Syndrome epidemic in Saudi Arabia: A cross sectional study", Saudi Journal of Biological Sciences, 25 (3), 572-577 (2018).

26- RASOFT online freely available program Raosoft Inc. http://www.raosoft.com/ samplesize.html (2004).

27- L. J. Cronbach, "Coefficient alpha and the internal structure of tests", Psychometrika, 16, 297-334 (1951).
28- The Central Agency for Public Mobilization and Statistics; CAPMAS (2020), Available at https://www.capmas. gov.eg/Pages /popul ation Clock.aspx\#). (Accessed on 30th May 2020).

29- H. M. Hassan, "Knowledge, attitude and belief of Al-Ghad College students toward coronavirus Infection, Riyadh, Saudi Arabia", International Journal of Medical Research Reviews, 4, 19-26 (2016).

30- J. Yang, Y. Zheng, X. Gou, K. Pu, Z. Chen, Q. Guo, R. Ji, H. Wang, Y. Wang and Y. Zhou, "Prevalence of comorbidities in the novel Wuhan coronavirus (COVID19) infection: A systematic review and meta-analysis", International Journal of Infectious Diseases, doi:10.1016/j.ijid. 2020.03.017 (2020).

31- M. S. Wolf, M. Serper, L. Opsasnick, R. M. O'Conor, L. M. Curtis, J. Y. Benavente, G. Wismer, S. Batio, M. Eifler, P. Zheng, A. Russell, M. Arvanitis, D. Ladner, M. Kwasny, S. D. Persell, T. Rowe, J. A. Linder and S. C. Bailey, "Awareness, attitudes and actions related to COVID19 among adults with chronic conditions at the onset of the U.S. Outbreak: A Cross-sectional survey", Annals of Internal Medicine, doi:10.7326/M20-1239 (2020).

32- A. Extance, "Covid-19 and long term conditions: What if you have cancer, diabetes, or chronic kidney disease?", British Medical Journal, 368, m1174 (2020). 


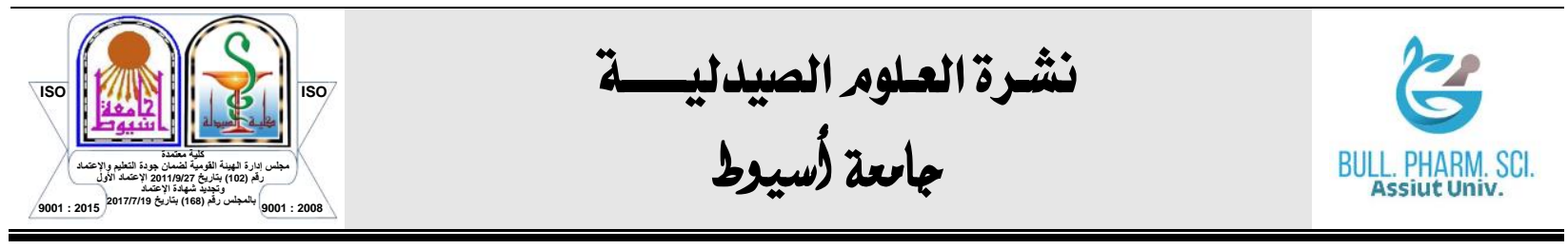

\section{معرفة وإدرالك المصريين عن تفشى مرض فيروس كورونا المستجد}

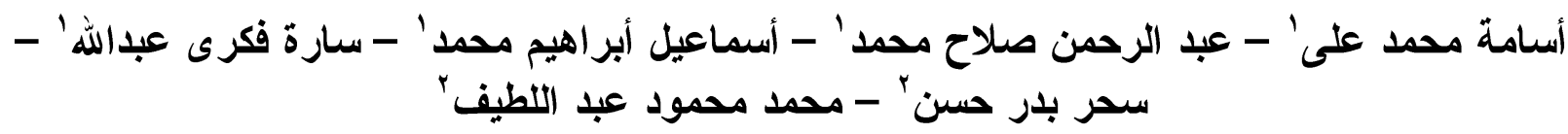

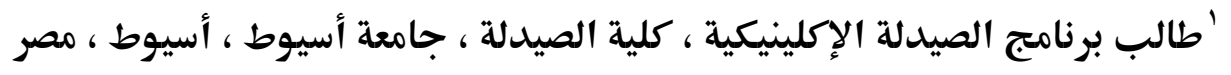

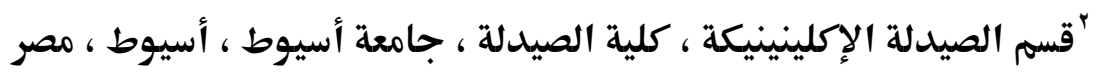

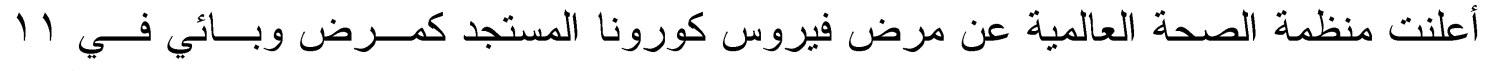

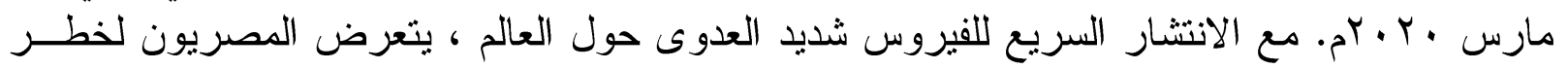

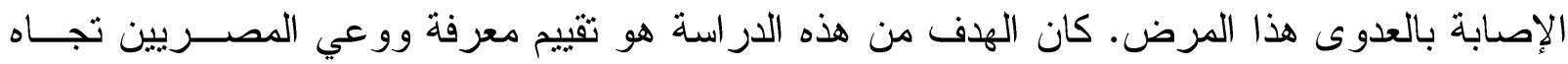

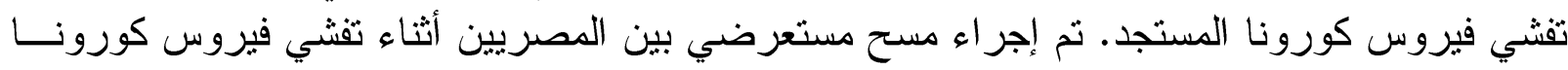

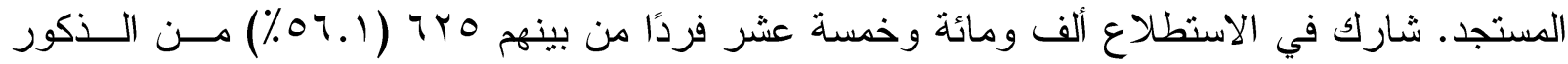

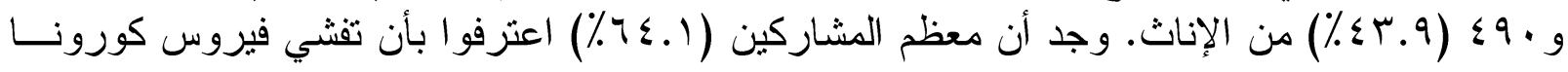

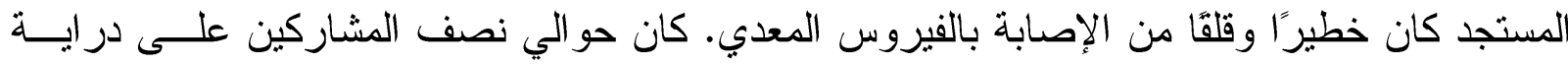

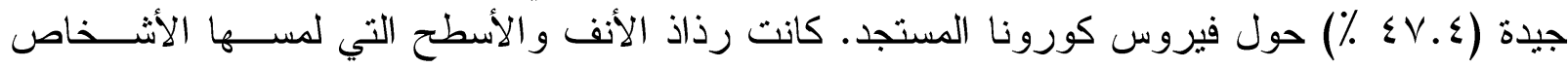

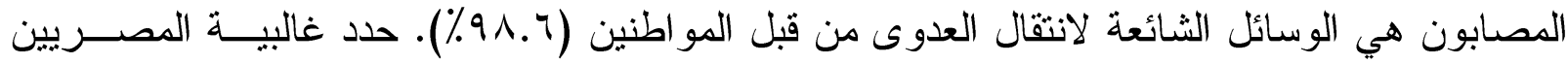

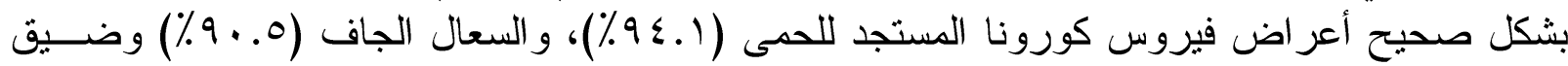

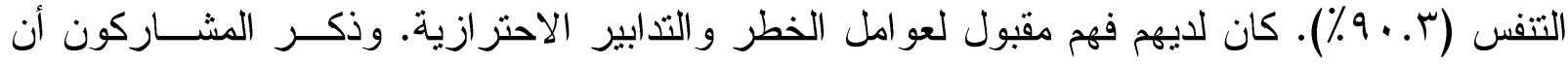

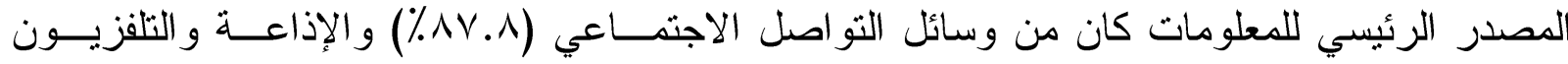

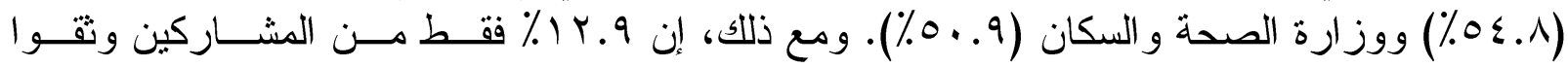

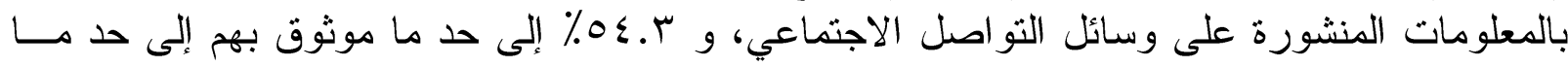

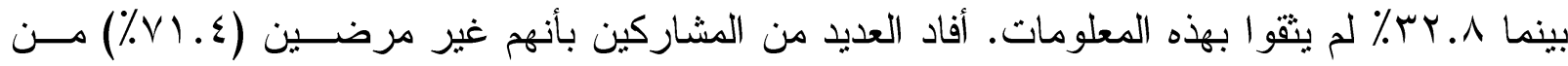

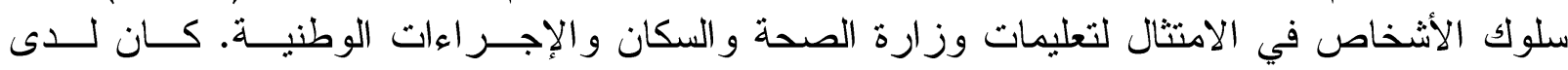

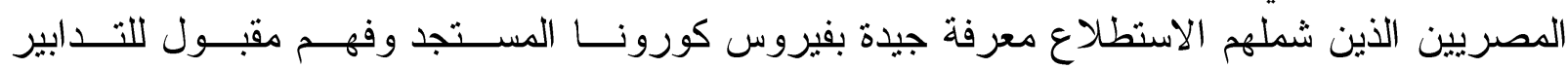

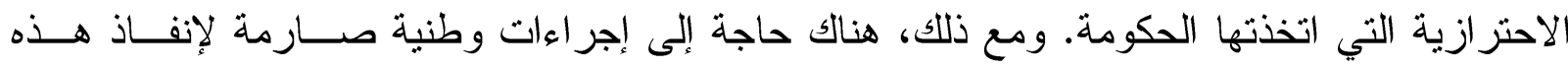
الإجر اءات الإحتر ازية بين الموالنين لمكافحة المرض. لماك. 